\title{
Problems and Challenges in the Employment Development during Covid-19 Pandemic in the Era of the Industrial Revolution 4.0 (Case of East Java Province, Indonesia)
}

\author{
Himawan Estu Bagijo ${ }^{1.4}$, Hendrawan Dendy Santoso ${ }^{2}$, Maria Dwi Susanti ${ }^{3}$ \\ ${ }^{1.2 .3}$ Department of Manpower and Transmigration of East Java Province \\ ${ }^{4}$ Wisnuwardhana University, Malang, Indonesia \\ him_estu@yahoo.com
}

\begin{abstract}
The purpose of this study is to discuss the role of employment development carried out by the Department of Manpower and Transmigration of East Java Province to companies and workers affected by the Covid-19 Pandemic. The research used random sampling, involving 859 companies in East Java with a reported number of 316,497 workers. The qualitative research method is descriptive analysis based on data on the impact of the Covid-19 pandemic, namely the number of layoffs (terminations), the number of workers laid off, the number of workers minus wages, and the number of companies closed/not operating. The results of the analysis have revealed that the government plays an important role in efforts to foster and protect the law on the implementation of public policies in the form of labor regulations during the Covid-19 pandemic in the Industrial Revolution 4.0 era. Suggestions for the formulation of further employment public policies reduce the incidence of employment problems and create peace at work.
\end{abstract}

Keywords-Employment Development, Legal Protection, Industrial Relations.

\section{INTRODUCTION}

Worker is any person who works by receiving wages or other forms of remuneration [1]. The results of the work in the form of goods or services are replaced in the form of wages by the entrepreneur [2]. When working in a company, there is an interaction between workers, therefore there is a need for a form of rule or law that is binding and becomes a guideline in the event of a dispute. [3].

Rules for the division of government affairs in the field of labor also exist [4]. As a consequence of this policy, labor inspectors were formed under the provincial government who were given the authority and responsibility to examine the enactment of labor regulations in the companies [5]. In terms of the geographical condition of the vast archipelago of Indonesia, the central government delegates authority to the heads of the provinces to act in providing guidance and supervision in each district or city [6]. The government of each province has its own authority to formulate their respective regional policies in terms of manpower in the form of guidance and supervision of manpower [7]. The government's policy direction regarding employment is motivated by the current development of business conditions and the prediction of future impacts. At the turn of the decade, these changes will occur, for example in the 20th century, many entrepreneurs want and make business innovations to reduce company financial expenditures, one of which is worker wages [8].

Currently, the global change in business conditions in various countries is known as the industrial revolution. The world has entered the era of the industrial revolution 4.0 characterized by increased knowledge and industrial technology in the form of a combination of the physical, digital and biological fields [9]. Various impacts of the industrial revolution 4.0 have occurred in Indonesia, including the development of digital progress in the use of economic and social aspects for the progress of the country. Of course, the legal function as a digital human and digital soft skills is still needed which aims to realize a sense of justice [10]. As with the development of labor law in 2020, the Indonesian state has issued a legal product from the Omnibus Law process [11]. Not only in Indonesia, but also in other countries such as Canada, the formulation of labor law policies aims to ensure the protection of workers in the workplace [12].

Employment law is very much needed to provide protection for workers in employment issues concerning the morals, ethics, and behavior of workers and employers [13]. Employment law must also remain relevant to the times. Revolution [14] means a fairly basic change in a field. Industry [15] means the activity of processing or processing goods using facilities and equipment, such as machines. Revolutions occur rapidly in the field of producing goods/services in order to have added value, such as changing the role of humans with machines. The way workers work which was originally manual has changed to automation or digital [16] 
Indonesia itself is also experiencing the era of the industrial revolution 4.0 where the system is digitally connected between the data of one agency and the data of other agencies [17]. As a result of the industrial revolution, in terms of the economy, it has a significant effect on gross domestic product in the first quarter of 2021, amounting to 2,684,019.00 GDP Series 2010 (Billion Rupiah) [18]. Another impact of the industrial revolution 4.0 is the flow of information that flows so fast through the internet network. However, the 4.0 industrial revolution like currency has a good side and a bad side. Therefore, the role of the government in charge of employment must be able to make regulations related to online business models that have the potential to cause inequality in the country's economy [18]. The focus of national industrial development in the era of the industrial revolution 4.0 is the optimal use of internet digital technology [18]. The government needs to be responsive and prepare strategic steps in welcoming and competing with other countries through accelerating the implementation of the industrial revolution 4.0. [18]. At the time of the industrial revolution 4.0, Law no. 13 of 2003 is still felt the need for changes because in the year the policy formulation only regulates the rights and obligations for work directly, this is different from this year the work without an employment relationship with partnership status has not been regulated in detail [19].

In 2019 is a crucial year for the Indonesia, because that year the government was challenged to solve global problems. The Covid-19 virus is not only spreading in the community, but the daily interactions of workers in the workplace also can trigger the spread of this virus. The existence of new clusters in the spread of the Covid-19 pandemic, is one of which was reported in the electronic mass media that occurred in the employment cluster [20]. This news illustrates the very fast spread of Covid-19 and it seems that no place is completely safe from contracting this virus [21]. The responsibility for the implementation of manpower development is carried out by labor inspectors located in each province of Indonesia. The preventive educative stages include fostering actions against labor norms to prevent violations of labor norms [23].

\section{RESEARCH METHOD}

This study discusses efforts to foster employment carried out by government agencies in the field of employment, especially the Department of Manpower and Transmigration of East Java Province during the Covid-19 pandemic era in the industrial revolution 4.0. The research method uses a qualitative descriptive analysis of the impact of the Covid-19 Pandemic in the employment sector including the number of layoffs, the number of workers being laid off, the number of workers minus wages, and the number of companies closed/not operating.

The data used in this study is data on employment conditions reports on the implementation of Emergency
PPKM (Implementation of Restrictions on Community Activities) in the workplace during the Covid-19 Pandemic through random sampling in the form of filling out an online assessment questionnaire for Emergency PPKM (Implementation of Restrictions on Community Activities) in the Workplace which was sent to company management in 38 districts/cities in East Java by labor inspector Disnakertrans Prov. East Java via whatsapp and email during the PPKM (Implementation of Restrictions on Community Activities) period, starting from 3 July 2021 to 18 August 2021. Data and information were collected in order to obtain primary, secondary, and tertiary legal materials for research materials [24]. Information on the number of workers and companies experiencing the impact of the Covid-19 pandemic in the era of the industrial revolution 4.0 was further processed to examine the implementation of employment development. Analysis and assessment of the impact of the Covid-19 Pandemic in the employment sector was sourced from data on handling employment cases in the Labor Inspection and K3 Sector and in the Industrial Relations Division of the East Java Province Manpower and Transmigration Office during the Covid-19 pandemic.

Manpower development by the Department of Manpower and Transmigration of East Java Province is carried out based on policies during the Covid-19 Pandemic, namely the government issued a policy in the form of Large-Scale Social Restrictions (PSBB) in 2020 and the Enforcement of Restrictions on Community Activities (PPKM) [25] in 2021 to deal with Covid-19 pandemic.

\section{FINDINGS AND DISCUSSION}

\section{Demographics of Respondent Companies.}

The results of the Implementation of Restrictions on Community Activities Emergency Workplace assessment survey, the number of companies as respondents was 859 companies spread over 37 districts/cities in East Java. The demographic summary of the respondents consists of 3 categories, namely the area of the company's location, the business sector, and the respondent's position in the company. The category of respondents based on the location of the company in East Java is divided into 6 regional coordinators for labor inspection with details of the Regency or City of each regional coordinator shown in Graph 1. Regional coordinator 1 includes Surabaya, Sidoarjo, Mojokerto, Pasuruan, and Gresik having the highest number of respondents, namely 37, $02 \%$. Furthermore, Regional coordinator 4 includes Lamongan, Tuban, Nganjuk, Jombang, Bojonegoro as much as $23.86 \%$ of the total respondents, Regional coordinator 2 includes Batu, Tulungagung, Malang, Blitar, Trenggalek as much as $17.11 \%$, Regional coordinator 5 covers Banyuwangi, Situbondo, Probolinggo, Lumajang, Jember, Probolinggo as much as $11.18 \%$, Korwil 3 covering Ponorogo, Madiun, Kediri, Ngawi, Pacitan, Magetan as much as $8.15 \%$, and Regional coordinator 6 Madura 
covering areas Bangkalan, Sumenep, Sampang, Pamekasan as much as $2.68 \%$. The business sector categories during the implementation of the Restrictions on Community Activities policy were categorized into 3, namely Critical, Essential and Non-Essential, with details per sector shown in Graph 2, with the largest number of respondents in the critical sector being $59.14 \%$.

Graph 1. Number of companies reporting the implementation of Emergency of the Implementation of Restrictions on Community Activities per Regional coordinator and per Regency/City in East Java Province

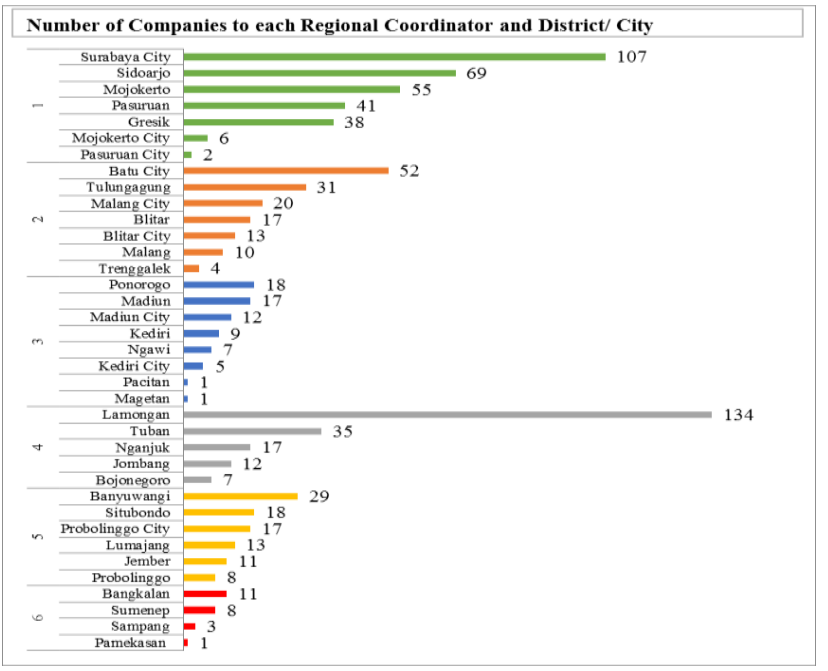

Source: Department of Manpower and Transmigration of East Java Province

In the Graph 1, the number of companies reporting the Emergency of the Implementation of Restrictions on Community Activities in the workplace, the incoming data are company respondents in 37 districts or cities from 38 districts or cities in East Java Province, only 1 area, namely Bondowoso Regency which has not returned the contents of the Emergency of the Implementation of Restrictions on Community Activities online assessment questionnaire. at workplace. Most of the feedbacks on the results of filling out research questionnaires were companies in the Lamongan Regency area as many as 134 companies. The percentage of companies that report the Emergency of the Implementation of Restrictions on Community Activities per Business Sector in East Java Province is the highest percentage of $59.14 \%$ companies in critical categories such as energy, health, security, logistics, transportation, food and beverage industries and their supports, petrochemicals, cement, vital objects national disaster management. The percentage of $26.89 \%$ is essential companies such as finance and banking, capital markets, payment systems, information and communication technology, hotels and handling of the Covid-19 quarantine. Finally, the percentage is $13.97 \%$ for companies in the non-essential category.
2. The Impact of the COVID-19 Pandemic on the Employment Sector during the Emergency of the Implementation of Restrictions on Community Activities Period.

The results of the study obtained data on the number of companies and workers confirmed to have COVID-19, closed or not operating, the number of workers being laid off, the number of workers whose wages were reduced, and also the number of layoffs during the Emergency of the Implementation of Restrictions on Community Activities period.

The recapitulation of the impact of the Covid-19 pandemic shows the number of companies with Covid-19 cases as many as 457 companies $(53.20 \%)$ of the 859 respondent companies with the number of confirmed Covid-19 workers as many as 15,721 people $(4.97 \%)$ out of a total of 316,497 people. labor. There were 50 companies $(5.82 \%)$ closed or not operating due to the Covid-19 pandemic with a total workforce of 4,688 people $(1.48 \%)$. The number of companies that laid off their workers was 81 companies $(9.43 \%)$ with the number of workers being laid off as many as 7,217 people $(2.28 \%)$. There were 102 companies $(11.87 \%)$ that reduced wages with the number of workers whose wages were reduced to 7,303 people $(2.31 \%)$. Meanwhile, 7 companies $(0.81 \%)$ had laid off workers with the number of workers laid off during the Emergency of the Implementation of Restrictions on Community Activities

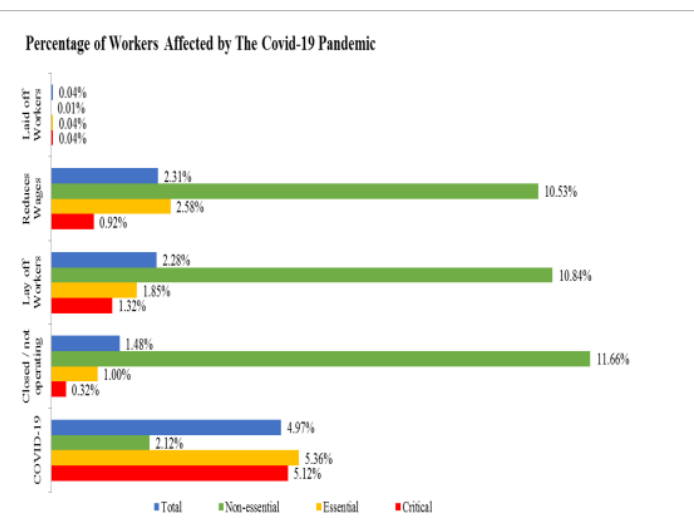

period as many as 115 people (0.04\%). Graph 2 . Percentage of Workers Affected by the Covid-19 Pandemic

Source: Department of Manpower and Transmigration of East Java Province

The spread of Covid-19 in the labor cluster certainly has an impact on workers. Companies affected by the Covid-19 pandemic in the 4.0 industrial revolution era include the tourism, hotel, restaurant and transportation services sectors. There are also companies who think not to report the implementation of Emergency of the Implementation of Restrictions on Community Activities in the workplace to the Department of Manpower and Transmigration of East Java Province. 
3. Employment Policy Against the Impact of the Covid19 Pandemic in the Employment Sector.

The 4.0 industrial revolution era saw significant changes due to technological innovations that affect the market, the distribution of goods and services traded via the internet is used to seek profit for companies [28]. The government's actions in 2019 were not only to accelerate implementation, but at the same time, also infectious diseases emerged to various countries in the world. These two major events led to soaring unemployment. Government policies to provide protection, work continuity, and business continuity, a minimum wage determination were issued in an effort to recover the economic sector during the Covid-19 pandemic [29]. As for the provisions of the work system, it implies that everyone has the right to social security that allows his development as a dignified human being [30].

\subsection{Closing / not operating company}

The most companies closed or not operating due to the Covid-19 pandemic were in the non-essential category of 23 companies with 2,958 workers. The sector is affected by tourist attractions, entertainment (karaoke), and travel services. Furthermore, the essential category was affected by 12 companies with 1176 workers, including the hotel sector, export-oriented industrial sectors such as charcoal briquettes. The smallest in the critical category is 15 companies with 554 workers, namely the food, beverage, and supporting industries including restaurants. The spread of Covid-19 that spreads in rural and urban areas. Many investors are reluctant to invest their capital because of the impact of the sluggish business world. Export-oriented companies are also considering tariffs on international trade transactions during the Covid-19 era of the industrial revolution 4.0 [19].

The condition of the company as a result of the Covid-19 pandemic needs to be reported to the employment agency, based on Article 8 paragraph (1) of Law Number 7 of 1981 concerning Mandatory Reporting on Employment in Companies that the entrepreneur or management is obliged to report in writing to the Minister or appointed official no later than within 30 (thirty) days prior to transferring, terminating or dissolving the company.

\subsection{Workers laid off}

The most companies that laid off workers during the Emergency of the Implementation of Restrictions on Community Activities period were in the critical category of 36 companies with 2,290 workers, mostly the food and beverage industry and its supporting sectors. Furthermore, the essential category was affected by 25 companies with 2,176 workers, namely the hotel sector and export orientation such as the footwear industry. Meanwhile, in the non-essential category, there were 20 companies with
2,751 workers, the tourism sector and the entertainment industry.

Company managers apply several strategies for worker efficiency, but the employer's strategy sometimes even causes turmoil about the work system in the company. Changes and work system rules applied by the company can result in employment cases. The Department of Manpower and Transmigration of East Java Province provides guidance to the parties in dispute regarding industrial relations. The implementation of this manpower development is a preventive judicial legal protection effort.

\subsection{Wage Reduction}

The most companies that reduced workers' wages during the Emergency of the Implementation of Restrictions on Community Activities period were in the essential category of 51 companies with 3,032 workers, namely the hotel sector and export-oriented industries such as charcoal briquettes and footwear. Furthermore, the critical category was affected by 32 companies with 1,599 workers, namely the transportation sector - bus rental, restaurants, and plantations. Meanwhile, in the non-essential category, there were 19 companies with 2,672 employees, namely beauty clinics and the tourism sector.

Employment cases regarding partnerships such as the wage payment system in the era of the industrial revolution 4.0 are interesting to be discussed in more depth. Payment for online transportation service fees is sent to the transportation company, then the transportation company provides incentives after meeting a certain threshold target. The law states that monetary rewards are wages [19]. Law Number 11 of 2020 has regulated the protection of workers regarding wages, the amount of wages using a formula, so that workers and entrepreneurs do not experience difficulties in determining wages in the era of the industrial revolution 4.0 [19].

The first impact related to workers' wages in the form of reduced wages is regulated in Article 41 paragraph (1) Government Regulation of the Republic of Indonesia Number 36 of 2021 concerning Wages written that wages are paid to workers/laborers who do not come to work and/or do not work because of illness like Covid-19. The second impact in the form of unpaid wages is regulated in Article 40 paragraph (1) of Government Regulation of the Republic of Indonesia Number 36 of 2021 concerning Wages, namely wages are not paid if the worker/laborer does not come to work and/or does not do the work

Point II paragraph (4) Circular Letter of the Minister of Manpower of the Republic of Indonesia Number M/3/HK.04/III/2020 concerning Protection of Workers/Labourers and Business Continuity in the Context of Prevention and Control of Covid-19 stipulates that for companies that restrict their business activities due to government policies in their respective regions for the prevention and control of COVID-19, thus causing some or all of the workers/laborers not to come to work, 
taking into account business continuity, changes in the amount and method of payment of workers/laborers' wages are carried out in accordance with the agreement between the entrepreneur and the worker/laborer.

\subsection{Termination of Employment}

Article 36 letter d of Government Regulation of the Republic of Indonesia Number 35 of 2021 concerning Work Agreements for Certain Time, Outsourcing, Working Time and Rest Time, and Termination of Employment in writing concerning companies closing due to force majeure.

Article 151 paragraph (3) of Law Number 13 of 2003 concerning Manpower Jo. Article 81 point 37 of Law Number 11 of 2020 concerning Employment Cluster Job Creation states that in the event that the bipartite negotiations as referred to in paragraph (3) do not get an agreement, the termination of employment is carried out through the next stage in accordance with the industrial relations dispute settlement mechanism.

There were 7 companies that carried out layoffs during the Emergency of the Implementation of Restrictions on Community Activities period with a workforce of 115 people, namely in the hotel sector, footwear industry, restaurants, and also P3MI (a company that distributes Indonesian migrant workers). The government's policy in the form of social security related to the issue of termination of employment regulates severance payments, maternity leave, long sick leave, and many other insurance protections [19]. Finally, the government issued a Job Loss Guarantee program, this program is intended for workers who have lost their jobs due to the Covid-19 pandemic [31].

Article 156 paragraph (1) of Law Number 13 of 2003 concerning Manpower Jo. Article 81 point 44 of Law Number 11 of 2020 concerning the Creation of Employment Clusters of Employment states that in the event of termination of employment, the employer is obliged to pay severance pay and/or service award money and compensation for entitlements that should have been received.

In addition, to reduce the increasing unemployment rate due to layoffs, local governments need to provide assistance to improve the competence of job seekers, such as local job seekers who are included in training and courses on computer technology and the development of information technology [26]. This effort is a form of accelerating implementation in the face of the industrial revolution 4.0 [27]. The Department of Manpower and Transmigration of East Java Province facilitated the training at the Job Training Centers located in 16 Regencies/Cities in the East Java Province.

\section{IV.CONCLUSION}

The law is needed to provide protection to the community, as well as rules for sanctions for those who violate it. The legal function of the industrial revolution 4.0 era is the protection of strategic data, the dignity of the state, defense, and legal entities in the Indonesian state. The government through its policies in the form of labor law seeks to adapt to the development of the industrial revolution 4.0 era. The success of the government's strategy is closely related to the quality of community resources and the regulations that govern them. Because of increasing the spread of Corona Virus Disease 2019 (COVID-19) in several regions of Indonesia and taking into account the official statement of the World Health Organization (WHO) which states COVID-19 as a global pandemic, it is necessary to take steps to protect workers/labor and business continuity. Circular Letter of the Minister of Manpower of the Republic of Indonesia Number M/3/HK.04/III/2020 concerning Protection of Workers/Labourers and Business Continuity in the Context of Prevention and Control of Covid-19.

\section{REFERENCES}

[1] Undang-Undang Republik Indonesia Nomor 13 Tahun 2003 tentang Ketenagakerjaan.

[2] Mardani Wijaya, et.al., "The Constitutional Right Of Citizens To Work In The Industrial Revolution Era 4.0" ,Jurnal IUS Kajian Hukum dan Keadilan, Vol. 7 No. 2, Agustus 2019.

[3] Ryan Bubb, "Choosing the Partnership: English Business Organization Law During the Industrial Revolution” ,Seattle University Law Review, Vol. 38:337, 2015.

[4] Huruf G Lampiran Undang-Undang Republik Indonesia Nomor 23 Tahun 2014 tentang Pemerintah Daerah.

[5] Peraturan Kepala Badan Kepegawaian Negara Nomor 48 Tahun 2015 tentang Pelaksanaan Pengalihan Pegawai Negeri Sipil Daerah Kabupaten/ Kota Yang Menyelenggarakan Pengawasan Ketenagakerjaan Menjadi Pegawai Negeri Sipil Daerah Provinsi.

[6] Rakha Anggara Widya Dhana, "Pelaksanaan Pasal 45 Ayat (2) Peraturan Pemerintah Republik Indonesia Nomor 44 Tahun 2015 Tentang Penyelenggaraan Program Jaminan Kecelakaan Kerja dan Jaminan Kematian (Studi di Dinas Tenaga Kerja dan Transmigrasi Provinsi Jawa Timur Kordinator Wilayah II Malang)",Jurnal Hukum, http://hukum.studetjournal.ub.ac.id., 2020 .

[7] http://disnakertrans.lomboktimurkab.go.id/baca-berita-162-peranpemerintah-ketenagakerjaan-dalam-perspektif- undangundangnomor-13-tahun-2003-tentang-ketenagak.html

[8] Sang M. Lee and David L. Olson, Convergenomics: Strategic Innovation in the Convergence Era, Publisher of Humanities, Social Science \& STEM Books, 2016.

[9] Klaus Schwab, The Fourth Industrial Revolution, Crown Business: New York, 2017.

[10] Ujang Suratno, Arah Pembaharuan Hukum Nasional Dalam Menghadapi Era Revolusi Industri 4.0, Universitas Wiralodra, Indramayu, n.d.

[11] Undang-Undang Republik Indonesia Nomor 11 Tahun 2020 tentang Cipta Kerja.

[12] Claire Mumme, "The State Giveth and Taketh Away: Public Sector Labour Law, the Legitimacy of the Legislative Override Power and Constitutional Freedom of Association in Canada", International Journal of Comparative Labour Law and Industrial Relations, Vol. 36, Issue 4 pp. 495 - 522, 2020.

[13] Hendrawan Dendy Santoso, Edisi Revisi Perspektif Biaya Upah Tenaga Kerja Bagi pengusaha dan Pekerja, Malang: Kota Tua, 2019.

[14] https://kbbi.kemdikbud.go.id/entri/revolusi

[15] https://kbbi.kemdikbud.go.id/entri/industri

[16] Edison H. Manurung and Ina Heliany, "Peran Hukum Dan Tantangan Penegak Hukum Dalam Menghadapi Era Revolusi Industri 4.0" ,Sol Justisio : Jurnal Penelitian Hukum, Vol. 1 Nomor 2, Oktober 2019. 
[17] Nova Jayanti Harahap and Mulya Rafika, "Industrial Revolution 4.0: And The Impact On Human Resources" Jurnal ECOBISMA, Vol. 7 Nomor 1, 2020.

[18] https://www.bps.go.id/indicator/11/65/1/-seri-2010-pdb-seri$\underline{2010 . h t m l}$

[19] Ike Farida, "Recent Development of Legal Framework of Labor Law in Indonesia" The 4th JILPT Tokyo Comparative Labor Policy Seminar 2020 Japan Labor Issues, Vol.5, Nomor 32, July 2021.

[20] https://mediaindonesia.com/read/detail/329192-awas-lingkungankerja-jadi-klaster-penularan-covid-19, 2020.

[21] Hendrawan Dendy Santoso, “Apa Hanya Masker" Call For Papper Peranan Pengawas Ketenagakerjaan Di Era Covid-19 Kementerian Ketenagakerjaan Republik Indonesia, 2020.

[22] https://kumparan.com/tugumalang/kerja-berdempetan-apd-takada-buruh-pabrik-roko-di-malang-mogok-kerja1tAiGy7gDzp,2020

[23] Peraturan Menteri Ketenagakerjaan Republik Indonesia Nomor 1 Tahun 2020 tentang Perubahan Atas Peraturan Menteri Ketenagakerjaan Nomor 33 Tahun 2016 tentang Tata Cara Pengawasan Ketenagakerjaan.

[24] Sunaryati Hartono, Penelitian Hukum di Indonesia Pada Akhir Abad ke-20, Bandung: Alumni, 1994.

[25] https://id.wikipedia.org/wiki/Pemberlakuan_pembatasan_ kegiatan masyarakat_di Indonesia

[26] Randi, et.al. "Potential Candidates For Village Youth Labor In The Era Of Industrial Revolution 4.0 And Covid 19 Pandemic (Study on Tanjung Medang Village Youth)" The 3nd International Conference on Technology, Education, and Social Science, 2020.

[27] Venti Eka Satya, "Strategi Indonesia Menghadapi Industri 4.0" INFO Singkat Kajian Singkat Terhadap Isu Aktual dan Strategis, Vol. X, Nomor 09, 2018

[28] MinHwa Lee, et.al., "Article How to Respond to the Fourth Industrial Revolution, or the Second Information Technology Revolution? Dynamic New Combinations between Technology, Market, and Society through Open Innovation" J. Open Innov. Technol. Mark. Complex, 2018.

[29] Surat Edaran Menteri Ketenagakerjaan Republik Indonesia Nomor M/11/HK.04/X/2020 Tahun 2020 tentang Penetapan Upah Minimum Tahun 2021 Pada Masa Pandemi Corona Virus Disease 2019 (Covid-19).

[30] Peraturan Pemerintah Nomor 35 Tahun 2021 tentang Perjanjian Kerja Waktu Tertentu, Alih Daya, Waktu Kerja dan Waktu Istirahat, dan Pemutusan Hubungan Kerja.

[31] Peraturan Pemerintah Republik Indonesia Nomor 37 Tahun 2021 tentang Penyelenggaraan Program Jaminan Kehilangan Pekerjaan.

[32] Sanusi, et.al., Hukum Yang Responsif Terhadap Revolusi Industri 4.0 Dalam Perspektif Pancasila, Prosiding Seminar Nasional Hukum Trasendental, Program Doktor Ilmu Hukum Universitas Muhammadiyah Surakarta, 2019 